\title{
REVITALISASI ETIKA BISNIS DALAM MEMBANGUN SISTEM PEREKONOMIAN YANG BERADAB
}

\author{
Ma'mun Mu' $\mathbf{m i n}^{1}$
}

\begin{abstract}
Abstrak
The revitalization of business ethics in the global economic system today urged to be done given the global economic competition tend to justifies any with regard not business ethics. Business Ethics so very important done especially in arranging business relationship with the parties that are related with good nature, environment, companies and individuals. Do business with regard not the ethics of course will result in injustice, evil and destruction, or at least no parties who are disadvantaged because of the fraudulent behavior. The revitalization of business ethics in order to build the economy that civilized so urgent and urgent. Among the business ethics that must be were revitalized, namely values of honesty, trust responsible, moral courage, fairness, realistic and critical, humble respect for stakeholders.
\end{abstract}

Key words: Revitalization, ethics, global economy

\section{A. Pendahuluan}

Revitalisasi etika bisnis dalam sistem perekonomian global dewasa ini mendesak untuk dilakukan, mengingat persaingan perekonomian global cenderung menghalalkan segala cara dengan tidak mengindahkan etika bisnis. Etika bisnis begitu sangat penting dilakukan terutama dalam mengatur hubungan bisnis dengan para pihak yang terkait, baik dengan alam, lingkungan, perusahaan dan perorangan. Berbisnis dengan tidak mengindahkan etika tentu saja akan berakibat ketidakadilan, malapetaka dan kehancuran, atau paling tidak ada pihak yang dirugikan karena perilaku curang. Di sini dapat disebutkan dua kasus bisnis yang tidak mengedepankan etika atau lalai etika, seperti kasus semburan lumpur Lapindo dan perselisihan pemilik hak paten antara Samsung, Android dan Apple.

1 Dosen STAIN Kudus. 
Pada kasus lumpur Lapindo, berdasarkan hasil penelitian yang dilakukan para ilmuan dari berbagai negara yang dipimpin oleh Profesor Richard Davies dari Universitas Durham Inggris, seperti dimuat dalam Jurnal Marine and Petroleum Geology (2010) menyimpulkan bahwa penyebab semburan lumpur Lapindo dikarenakan oleh kekeliruan dalam sistem pengeboran yang dilakukan oleh PT. Lapindo Brantas. Seperti disampaikan dalam serangkaian konferensi internasional yang diselenggarakan oleh pihak yang netral, diperoleh kesimpulan akhir bahwa penyebab semburan lumpur panas di Sidoarjo karena adanya kesalahan operasi PT. Lapindo Brantas. Dalam hal ini ketika Lapindo mengebor lapisan bumi dari kedalaman 3580 kaki sampai ke 9297 kaki, Lapindo belum memasang casing 9-5/8 inchi. Ini bentuk kelalaian Lapindo sehingga ketika terjadi loss dan kick Lapindo tidak mampu menutup lubang sumur yang menyemburkan lumpur panas. Namun pihak PT. Lapindo membantah bahwa penyebab lumpur karena gemba bumi Yogyakarta yang terjadi pada tanggal 27 Mei 2006, dua hari sebelum terjadi semburan lumpur Lapindo.

Pada kasus perselisihan hak paten antara Samsung, Android dan Apple, seperti dimuat dalam artikel Bussines Week (29 Maret 2012), memaparkan perang hak paten antara Apple dan berbagai produsen yang memproduksi produk-produk Android, artikel itu memberikan rincian bagaimana Apple terlibat dalam litigasi paten dengan sejumlah pembuat smartphone Android, termasuk Samsung, Motorola dan High Tech Computer (HTC) Corporation. Dalam perang paten Smartphone, banyak hal yang dipertaruhkan. Menurut pengacara dari Lathan and Watkins, Max Grant, seperti dikutip majalah Bloomberg (24 Agustus 2012). Menurut dia, ketika persoalan hak cipta sudah sampai di maja hijau, maka perusahaan tidak lagi memikirkan bagaimana mereka harus menghemat pengeluaran kauangan. Sebagai gambaran, menurut Max Grant, pengacara Apple memperoleh komisi USS 1.200 atau Rp 11,3 juta per jamnya untuk meyakinkan hakim dan juri bahwa Samsung Electronics Co telah menyontek desain Smartphone Apple. Perusahaan Apple juga sudah menghabiskan dana USS 2 juta atau Rp. 18,9 miliar hanya untuk menghadirkan saksi ahli. Bagi Apple tentu saja dana itu tidak seberapa, sebagai contoh biaya USS 32 juta yang dikeluarkan 
Apple dalam perang paten melawan Motorola Mobility setara dengan hasil penjualan Apple iPhone selama enam jam.

Kedua kasus tersebut menegaskan betapa revitalisasi etika bisnis menjadi sangat penting dan mendesak dilakukan, terutama untuk menjaga hak dan kewajiban semua pebisnis dan konsumen sehingga tidak terdapat pihak-pihak yang dirugikan, sehingga terwujud sistem perekonomian yang beradab.

\section{B. Konsep Etika Bisnis}

Ditinjau dari asal-usul kata, istilah etika berasal dari bahasa Yunani kuno ethos, yang berarti etika, etis, cara pandang dan sistem nilai yang dipakai dalam suatu kelompok (Ongky Setio Kuncono, 2013). Dalam Concise Oxford Dictionary (1974) kata ethos didefinisikan sebagai characteristic spirit of community, people or system (suasana khas yang menandai suatu kelompok bangsa atau sistem). Sementara menurut K. Bertens (2007: 224) istilah setika diartikan sebagai tempat tinggal yang biasa, padang rumput, kandang atau gudang, kebiasaan, adat, akhlak, watak, perasaan, sikap dan cara berpikir. Sehingga dalam bentuk jamaknya ta etha diartikan sebagai adat kebiasaan.

Secara bahasa (etimologi) menurut Noviliadi (2009: 4), istilah ethos berarti tempat hidup yang dimaknai sebagai adat istiadat atau kebiasaan. Dari kata ethos muncul istilah ethikos yang berarti teori kehidupan atau dalam istilah teori ilmu disebut etika. Dalam Kamus Besar Bahasa Indonesia (1995) etika adalah nilai mengenai benar atau salah yang dianut oleh suatu golongan atau masyarakat. Menurut Maryani dan Ludigdo (2001), etika adalah seperangkat aturan, norma atau pedoman yang mengatur perilaku manusia, baik aturan yang harus dilakukan maupun aturan yang harus dihindari oleh sekelompok manusia, golongan atau profesi.

Menurut penulis etika merupakan bagian dari kajian filsafat, biasa disebut filsafat etika atau filsafat moral, yaitu kajian filsafat yang memfokuskan kajiannya pada pencarian akan hakikat sistem nilai yang harus diikuti umat manusia (Ma'mun Mu'min, 2014). Namun menurut Poedjawiyatna (2003), etika bukan merupakan bagian dari filsafat. Sebagai ilmu, etika mencari keterangan (benar) yang sedalam-dalamnya. Sebagai tugas tertentu bagi etika, ia mencari ukuran baik-buruk bagi 
tingkah laku manusia, memang apa yang ditemukan oleh etika mungkin jadi pedoman seseorang, tetapi tujuan etika bukanlah untuk member pedoman, melainkan untuk tahu.

Semantara secara istilah (terminologi) kata ethos digunakan dalam tiga pengertian, yaitu: (1) Suatu aturan umum atau cara hidup, (2) Suatu tatanan dari perilaku, dan (3) Penyelidikan tentang jalan hidup dan seperangkat atau etiket atau cara bersopan santun (Ongky Setio Kuncono, 2013). Senada dengan Syukur (2004), istilah etika serign digunakan dalam tiga pengertian, yaitu: (a) merupakan pola umum atau jalan hidup, (2) seperangkat aturan atau kode moral, dan (3) penyelidikan jalan hidup dan aturan-aturan perilaku atau merupakan penyelidikan tentang hakekat dan dasar-dasar moral. Sehingga dari kata ethos ini terbentuk kata ethic, yang berarti pedoman hidup, moral dan perilaku atau etiket yaitu cara bersopan santun. Menurut Sonny Keraf (1998) etika adalah sebuah refleksi kritis dan rasional mengenai nilai dan norma moral yang menentukan dan mewujud dalam sikap dan pola perilaku hidup manusia baik secara peribadi maupun kelompok.

Dapat disimpulkan, ethos atau etika adalah sebagai suatu nilai-nilai atau norma-norma moral yang menjadi pegangan hidup bagi seseorang atau suatu leompok masyarakat dalam mengatur tingkah laku kehidupannya, secara individu maupun kelompok, terkait kehidupan dengan sesama manusia, dengan alam, dan dengan Tuhan.

Sementara menurut Bertens (2000: 36), etika bisnis berasal dari bahasa Inggris business ethics, dalam bahasa Belanda bedrijfsethick atau etika perusahaan, dan dalam bahasa Jerman Unternehmensethik atau etika usaha. Menurut Yosephus (2010: 79), etika bisnis pada dasarnya merupakan applied ethics atau etika terapan. Etika bisnis merupakan wilayah penerapan prinsip-prinsip moral umum pada wilayah tindakan maausia dalam bidang ekonomi, seperti bisnis. Jadi, sasaran etika bisnis adalah perilaku moral pebisnis yang beraktivitas dalam bidang ekonomi. Menurut Ongky (2013) pengertian ini menjelaskan bahwa bagaimana para pelaku bisnis bertindak secara moral dalam melakukan bisnisnya. Etika bisnis mengacu kepada tindakan bisnis yang benar sesuai dengan norma-norma yang ada, yang saling bertautan dalam satu kesatuan kerangka yang 
utuh dan sistematis sehingga membentuk suatu teori etika bisnis.

\section{Membangun Perekonomian Beradab}

Kemajuan sains dan teknologi serta semakin modern umat manusia ternyata tidak selalu seiring dan sejalan dengan perilaku umat manusia yang beradab. Kita tidak dapat menutup mata, dewasa ini dalam kondisi manausia semakin modern, muncul kecenderungan perilaku dan tindakan manusia semakin jauh dari beradab, tidak terkecuali dalam prilaku dan tindakan ekonomi. Dua kasus yang diutarakan diawal artikel ini bisa dijadikan bukti betapa manusia yang semakin modern ternyata perilaku ekonominya tidak semakin beradab. Ekonomi beradab yaitu perilaku ekonomi yang didasarkan pada etika bisnis seperti dikemukakan di atas.

Terkait dengan usaha membangun perekonomian yang beradab perlu diadakan revitalisasi etika bisnis, dalam hal ini Ongky Setio Kuncono (2013) mengajukan delapan dasar pijakan yang harus dijungjung tinggi para pelaku bisnis yang beradab, yaitu:

(1) Berpegang teguh pada kejujuran

Secara umum kejujuran diakui sebagai keutamaan atau sikap moral pertama sekaligus terpenting yang harus dimiliki oleh para pebisnis sebagai makhluk beretika, sampai saat ini diakui bahwa kejujuran identik dengan kesesuaian antara kata-kata atau ucapan dengan fakta dan perbuatan. Dalam praksis hidup, orang lebih cenderung memaknai kejujuran dalam pengertian tidak berbohong atau tidak menipu. Seorang pebisnis disebut orang jujur jika segala perkataan yang diucapkan, termsuk janji-janjinya sesuai dengan fakta dan tindakannya, yakni menepati janji-janjinya. Apa yang dijanjikan dalam kontrak atau kesepakatan atau transaksi entah dengan pihak luar (mitra bisnis dan pelanggan konsumen) atau dengan pihak dalam perusahaan selalu ditepati. Pebisnis yang jujur tentu akan menganggap kebohongan sebagai sesuatu yang tabu untuk dilakukan, sebab kejujuran kerap dirasakan sebagai sesuatu yang sangat mahal.

(2) Memegang teguh kepercayaan 
Sebagai keutamaan yang wajib dimiliki oleh para pebisnis, kepercayaan selalu bersifat timbal balik. Maksudnya, pembisnis yang selalu percaya kepada pihak lain mengandaikan bahwa pihak-pihak lain, apakah karyawan, mitra bisnis dan pelanggan akan mempercayainya juga. Ciri timbal balik dalam hal kepercayaan juga menuntut sikap kritis dari seorang pebisnis. Seorang pebisnis juga harus bersikap selektif dalam memilih mitra bisnis, termasuk menyeleksi dan memilih karyawan atau stafnya. Seorang pebisnis juga harus mengendalikan strategi dan taktik yang sangat menentukan bagi keberhasilan kegiatan bisnis untuk mencapai tujuan tersebut. Pada tatanan strategi dan taktik inilah sikap-sikap moral yang kuat, khususnya kepercayaan selalu mendapatkan tanggapan berat. Kesamaan tujuan mengindikasikan bahwa sikap yang bertentangan dengan kepercayaan bukan tabu untuk dilakukan oleh pebisnis. Pada tatanan ini, selektivitas dalam memilih mitra bisnis dan dalam menerima karyawan merupakan kata kunci yang tidak bisa ditawartawar.

(3) Bertanggung jawab

Sebagai keutamaan etika bisnis, tanggungjawab merupakan sikap terhadap tugas yang membebani seorang pebisnis dan karyawan atau staf. Baik pengusaha maupun karyawan merasa terikat untuk melaksanakan dan menyelesaikan tugas yang diemban atau dipercayakan. Tanggung jawab tidak pernah memberi ruang untuk sikap-sikap negatif, seperti malas, acuh tak acuh dan ragu-ragu. Sikap tanggungjawab menuntut bahwa sesuatu itu dilakukan dan diselesaikan dengan sebaik-baiknya. Dalam bahasa etika, tugas yang dilakukan secara bertanggungjawab disebut sebagai tugas mulia karena harus dilakukan dengan sebaik-baiknya walau tidak ada yang mengawasi pelaksanaannya.

Selanjutnya pebisnis yang bertanggungjawab pastilah orang-orang yang selalu bersedia dimintai dan memberikan pertanggungjawaban atas pelaksanaan tugas dan kewajiban, termasuk jika mereka lalai dalam 
pelaksanaan tugas dan tanggungjawab. Pebisnis yang bertanggung-jawab selalu siap menjadi good risk-taker. Mereka tidak pernah melemparkan tanggungjawab. Kesediaan untuk bertanggung jawab merupakan entrypoint yang dapat mengantarkan seseorang ke singgasana moralitas sebagai good risk-taker.

(4) Memiliki keberanian moral

Keberanian moral selalu berkaitan dengan kemampuan intelektual untuk menentukan penilaian sendiri terhadap sesuatu. Keberanian moral terlihat dengan sangat jelas ketika mereka menolak tegas untuk melakukan hal-hal yang bertentangan dengan etika bisnis dan hukum yang ditawarkan kepada mereka, meskipun mereka sebenarnya membutuhkan atau ada kesempatan yang memadai untuk melakukan hal itu, misalnya kesempatan untuk melakukan korupsi, kolusi dan nepotisme atau mengambil keuntungan pribadi walaupun untuk penolakan dalam hal-hal seperti itu mereka akan dikucilkan atau dicela oleh yang lain. Pebisnis yang memiliki keberanian moral selalu menjadikan dirinya sendiri sebagai pijakan bagi kaum yang lemah, atau yang mederita karena tingkah serta tindakan kelompok kuat atau pihak yang berkuasa.

(5) Memiliki fairness

Sering orang mengidentikkan fairness dengan rasa adil, namun ketika diterapkan ternyata tidak sama dengan keadilan. Fairness juga diidentikkan dengan sikap sportif, ketika diterapkan dalam kondisi konkret ternyata tidak juga persis sama dengan sportifitas. Sesuatu kondisi yang persis mewakili pengertian istilah fairness adalah kesediaan memberikan apa yang patut diberikan kepada semua orang. Pada tatanan bisnis, kata patut di sini menunjuk kepada apa yang dapat diterima atau disetujui oleh semua pihak yang terlibat dalam suatu transaksi bisnis. Seorang pebisnis dapat dikategorikan sebagai seorang yang memiliki keutamaan ini jika pebisnis tersebut selalu bersedia memberikan apa yang patut diberikan kepada pihak lain, apakah karyawan, pemasok dan pelanggan dalam kaitannya dengan hak 
Revitalisasi Etika Bisnis dalam Membangun Sistem ...

dan kewajiban.

(6) Bertindak realistis dan kritis

Keutamaan sikap moral realistik dan kritis lebih berkaitan dengan wilayah kognitif atau intelektual manusia, termasuk para pebisnis. Dalam berbisnis, setiap pengusaha akan menghadapi berbagai macam orang dengan berbagai latar belakang, seperti sosial, budaya, ekonomi, pendidikan, dan agama. Dalam keberagaman itu para manajer dan karyawan memiliki harapan, komitmen dan tingkat loyalitas yang berbeda. Dalam menghadapi keberagaman latar seperti itu, seorang pebisnis terpanggil untuk bertanggungjawab terhadap hidup mereka. Para manajer dan karyawan yang berasal dari latar belakang berbeda adalah identik dengan menegaskan orang-orang seperti itu adalah orang-orang riil. Konsekuensinya, seorang pebisnis harus berlaku riil dalam tanggungjawabnya terhadap mereka. Pebisnis harus membuka mata fisik dan mata pikiran terhadap realita yang ada, baik yang menyangkut perusahaan atau usahanya maupun menyangkut kondisi riil pegawainya. Dengan cara seperti itu seorang pebisnis yang baik secara moral akan melaksanakan tanggung-jawabnya dengan baik. Seorang pebisnis harus bersikap realitis dalam tutur kata dan tindakannya, bukan bersembunyi dibalik ungkapan-ungkapan yang kabur maknanya.

(7) Rendah hati

Harus digaris bawahi bahwa sikap moral dan rendah hati tidak ada sangkut pautnya dengan rasa sungkan kepada atasan atau rekan kerja yang lebih tua usianya, enggan untuk membela suatu pendirian atau merendahkan diri ke kuasa pimpinan. Seseorang melihat dirinya sendiri apa adanya, apakah sebagai karyawan, manajer atau sebagai pimpinan puncak sebuah bisnis. Dalam konteks bisnis, sikap rendah hati merupakan kekuatan batin yang membuat semua pihak yang terlibat untuk melihat diri dan menampilkan dirinya apa adanya.

(8) Memiliki rasa hormat

Sebagai keutamaan etika bisnis, rasa hormat terhadap diri sendiri atau orang lain merujuk kepada 
suatu kewajiban yang sebenarnya ditujukan kepada diri sendiri dan terhadap orang lain. Hormat terhadap diri sendiri dan orang lain atau sesama berarti bahwa manusia wajib memperlakukan dirinya sendiri dan orang lain sebagai yang bernilai. Hal ini didasarkan pada prinsip umum bahwa manusia merupakan pusat dari segala pengertian, kehendak, memiliki kebebasan dan suara hati serta merupakan insan yang berakal budi. Rasa hormat sangat dibutuhkan seorang pebisnis.

\section{Simpulan}

Revitalisasi etika bisnis dalam rangka membangun perekonomian yang beradab demikian urgen dan mendesak. Diantara etika bisnis yang harus direvitalisasi, yaitu nilai-nilai kejujuran, kepercayaan, bertanggung jawab, keberanian moral, fairness, realistis dan kritis, rendah hati, rasa hormat terhadap stakeholders. 


\section{DAFTAR PUSTAKA}

Ferry Novliadi, Hubungan antara Persepsi Terhadap Organisasi Pembelajar dengan Job Insecurity pada Karyawan, Medan, USU Press, 2009.

Jurnal Marine and Petroleum Geology, 2010. Diakses tanggal 9 November 2015.

K. Bertens, Etika, Jakarta, Gramedia Pustaka Utama, 2007.

L. Sinuor Yosephus, Etika Bisnis, Jakarta, Yayasan Obor Indonesia, 2010.

Ma'mun Mu'min, Filsafat Ilmu: Analisis Ilmu Pendidikan, Agama dan Moralitas, Yogyakarta, Ideal Press, 2014.

Ongky Setio Kuncono, Pengaruh Etika Confucius Terhadap Kewirausahaan, Kemampuan Usaha dan Kinerja Usaha Pedagang Eceran Etnis Tionghoa di Surabaya, Surabaya, Ringkasan Disertasi, 2013.

Poedjawiyatna, I.R., Etika: Filsafat Tingkah Laku, Jakarta Rineka Cipta, 2003.

Sonny Keraf, Etika Bisnis, Jakarta, Penerbit Kanisius, 1994.

Von der Embse dan R.A. Wagley "Managerial Ethics Hard Decisions on Soft Criteria", dalam Advance Managemen Jouurnal, 1988.

www.Bussines Week.com, 29 Maret 2012. Diakses tanggal 9 November 2015. 
